\title{
Preparation, crystallization, microstructure and dielectric properties of lead bismuth titanate borosilicate glass ceramics
}

\author{
Chandkiram R. GAUTAM ${ }^{a,}{ }^{*}$, Abhishek MADHESHIYA $^{a}$, Ranabrata MAZUMDER $^{b}$ \\ ${ }^{a}$ Advanced Glass and Glass Ceramic Research Laboratory, Department of Physics, \\ University of Lucknow, Lucknow 226007, India \\ ${ }^{b}$ Department of Ceramic Engineering, National Institute of Technology, Rouerkela 769008, India
}

Received: April 10, 2014; Revised: May 15, 2014; Accepted: May 28, 2014

(CThe Author(s) 2014. This article is published with open access at Springerlink.com

\begin{abstract}
Various bulk and transparent glasses were prepared by rapid melt quenching technique in the glass system $55\left[\left(\mathrm{~Pb}_{x} \mathrm{Bi}_{1-x}\right) \mathrm{TiO}_{3}\right]-44\left[2 \mathrm{SiO}_{2} \mathrm{~B}_{2} \mathrm{O}_{3}\right]-\mathrm{La}_{2} \mathrm{O}_{3}(x=0-0.7)$. The X-ray diffraction (XRD) studies of the glass samples confirmed the amorphous nature. The differential thermal analyses (DTA) were carried out from room temperature to $900{ }^{\circ} \mathrm{C}$ with a heating rate of $10{ }^{\circ} \mathrm{C} / \mathrm{min}$. The DTA patterns of the samples showed one or more exothermic sharp peaks shifting towards lower temperature side with increasing concentration of bismuth oxide (BiO). On the basis of DTA results, the solid solution of bismuth titanum oxide $\left(\mathrm{Bi}_{2} \mathrm{Ti}_{2} \mathrm{O}_{7}\right) /$ lead bismuth titanium oxide $\left(\mathrm{Pb}_{3} \mathrm{Bi}_{4} \mathrm{Ti}_{6} \mathrm{O}_{21}\right)$ was precipitated in borosilicate glassy matrix as a major phase. The glasses were subjected to $4 \mathrm{~h}$ and $8 \mathrm{~h}$ heat treatment schedules to convert into glass ceramics. XRD analysis of these glass ceramic samples showed that the major crystalline phase of the entire glass ceramic samples with $0 \leqslant x \leqslant 0.5$ is found to have cubic crystal structure, while it is tetragonal for glass ceramic sample with $x=0.7$. The scanning electron microscopy (SEM) micrographs indicated the uniform distribution of $\mathrm{Bi}_{2} \mathrm{Ti}_{2} \mathrm{O}_{7}$ and $\mathrm{Pb}_{3} \mathrm{Bi}_{4} \mathrm{Ti}_{6} \mathrm{O}_{21}$ crystallites in the glassy matrix.
\end{abstract}

Keywords: lead bismuth titanate; differential thermal analysis (DTA); crystallization; scanning electron microscopy (SEM); dielectric behavior

\section{Introduction}

From the last four decades, after the remarkable discovery by Aurivillius of a new family of materials named after his name, a concerted effort by the researchers resulted in the discovery of various novel glass ceramics containing ferroelectric crystals such as $\mathrm{Bi}_{2} \mathrm{WO}_{6}, \mathrm{BiTiO}_{3},(\mathrm{Na}, \mathrm{K}) \mathrm{NbO}_{3}, \mathrm{BaTiO}_{3}, \mathrm{~Pb}_{5} \mathrm{Ge}_{3} \mathrm{O}_{11}$, $\mathrm{LiNbO}_{3}, \quad \mathrm{Bi}_{2} \mathrm{VO}_{5.5}, \quad \mathrm{Bi}_{2} \mathrm{GeO}_{5}$, solid solutions of $\mathrm{Pb}_{x} \mathrm{Ba}_{1-x} \mathrm{TiO}_{3}$ and $\mathrm{SrAl}_{2} \mathrm{Si}_{2} \mathrm{O}_{8}$ embedded in glassy

* Corresponding author.

E-mail: gautam_ceramic@yahoo.com matrix [1-11]. The most important applications of Aurivillius family of bismuth based ferroelectric materials involve a layered structure in capacitors, sensors, and piezoelectric and electro-optic devices, which is strongly influenced by the method of preparation [12-15]. Out of different preparation methods, crystallization from the glasses has been applied to synthesize the glass ceramics [16-20]. This method gives possibility of doping with different cations to improve the properties of the glasses and glass ceramics. It also allows to control the particle size evolution during the transition from amorphous to crystalline state and to achieve suitable 
crystallographic orientation in the polycrystalline materials [21]. $\mathrm{SiO}_{2}$ is introduced to change the melting conditions, while $\mathrm{Nd}_{2} \mathrm{O}_{3}$ addition to bismuth titanate effectively improves the electrical properties [22-30]. The glass ceramic route of preparing $\mathrm{BiTiO}_{3}$ is desirable to obtain the material and associated with pore free fine grains of microstructure embedded in the glassy matrix [2]. Besides controlling the crystallite size, this method also provides the control over the transparent characteristics of the parent glasses during the crystallization [31]. It was reported that glass nanocomposites comprising nanocrystallites of bismuth titanate (BiT), dispersed in a glassy matrix of strontium tetra borate $\left(\mathrm{SrB}_{4} \mathrm{O}_{7}, \mathrm{SBO}\right)$ achieved by the controlled crystallization of glasses [32]. It was observed that ultrasonic treatment (UST) of the glass samples with an aqueous suspension of BiT followed by conventional heat treatment yields the desired crystalline phase, which is otherwise difficult to obtain by conventional heat treatment. Gerth and Rüssel [18] have reported the crystallization behavior of $\mathrm{BiT}$ in the $\mathrm{Bi}_{2} \mathrm{O}_{3}-\mathrm{TiO}_{2}-\mathrm{B}_{2} \mathrm{O}_{3}$ system. However, they have observed the tendency of spontaneous devitrification, and only samples with thickness of only $1 \mathrm{~mm}$ could be produced with the system by employing cooling rate as high as $227^{\circ} \mathrm{C} / \mathrm{min}$ during casting of glass melt. Kojima et al. [16] prepared BiT glass ceramics by a twin-roller rapid quenching technique. Recently, the study on the fabrication of $\mathrm{K}_{2} \mathrm{O}-\mathrm{SiO}_{2}-\mathrm{Bi}_{2} \mathrm{O}_{3}-\mathrm{TiO}_{2}$ glasses in the silicate matrix has been reported. The glasses and their glass ceramics are produced by the simple conventional melt quenching technique followed by controlled heat treatment to obtain $\mathrm{BiTiO}_{3}$ crystal containing glass ceramic nanocomposites in bulk quantity [33]. More recently, Golezardi et al. [34] reported their work on crystallization behavior, microstructure and dielectric properties of lead titanate glass ceramics in the presence of $\mathrm{Bi}_{2} \mathrm{O}_{3}$ as a nucleating agent.

The present paper focuses on the crystallization, microstructure and dielectric properties of glass ceramics with varying $\mathrm{BiO}$ content. According to our knowledge, there is no report for the preparation of glass ceramics containing the phases of solid solution of bismuth titanum oxide $\left(\mathrm{Bi}_{2} \mathrm{Ti}_{2} \mathrm{O}_{7}\right) /$ lead bismuth titanium oxide $\left(\mathrm{Pb}_{3} \mathrm{Bi}_{4} \mathrm{Ti}_{6} \mathrm{O}_{21}\right)$ by melt quenching with participation of $\mathrm{SiO}_{2}$ and $\mathrm{La}_{2} \mathrm{O}_{3}$, and the preparation, crystallization, microstructure and dielectric behavior of $(\mathrm{Pb}, \mathrm{Bi}) \mathrm{TiO}_{3}$ borosilicate glass ceramic system have not been reported elsewhere either.

\section{Materials and methods}

\subsection{Glass preparation}

Analytical reagent grade chemicals $\mathrm{PbO}$ (Fisher Scientific, 99\%), $\mathrm{Bi}_{2} \mathrm{O}_{3}$ (Himedia, 99.99\%), $\mathrm{TiO}_{2}$ (Himedia, 99\%), $\mathrm{SiO}_{2}$ (Himedia, 99.5\%), $\mathrm{H}_{3} \mathrm{BO}_{3}$ (Himedia, 99.8\%) and $\mathrm{La}_{2} \mathrm{O}_{3}$ (Himedia, 99.9\%) were well mixed for $2 \mathrm{~h}$ in acetone media using mortar and pestle. Dried powders were melted in platinum crucible for $1 \mathrm{~h}$ in the temperature range of $1200-1270{ }^{\circ} \mathrm{C}$ under normal atmospheric condition depending on the composition. The melt was quenched by pouring it onto an aluminum mould and pressing with a thick aluminum plate. The glasses were then annealed at $400{ }^{\circ} \mathrm{C}$ for $4 \mathrm{~h}$.

\section{2 Density measurements}

The density of the prepared glasses and glass ceramic samples has been calculated by Archimedes principle [35]. Distilled water was used as the liquid medium. The density of these glasses and glass ceramic samples is listed in Tables 1 and 2, respectively. The following formula was used for determination of the density of glass samples:

$$
\text { Density }=\frac{W_{2}-W_{1}}{\left(W_{4}-W_{1}\right)-\left(W_{3}-W_{2}\right)}
$$

where $W_{1}$ is the weight of empty specific gravity bottle (g); $W_{2}$ is the weight of specific gravity bottle with sample (g); $W_{3}$ is the weight of specific gravity bottle with sample and distilled water (g); and $W_{4}$ is the weight of specific gravity bottle with distilled water $(\mathrm{g})$. The density of distilled water is $1.0 \mathrm{~g} / \mathrm{cm}^{3}$.

\subsection{X-ray diffraction measurements}

$\mathrm{X}$-ray diffraction (XRD) of powder glass samples was carried out using a Rigaku Miniflex-II X-ray diffractometer with $\mathrm{Cu} \mathrm{K \alpha}$ radiation to check the amorphous state of the prepared glass samples.

\section{4 Differential scanning calorimetry measurements}

Differential scanning calorimetry (DSC) was done using a DSC equipment model NETZSCH STA 449C from room temperature $\left(27{ }^{\circ} \mathrm{C}\right)$ to $900{ }^{\circ} \mathrm{C}$ employing a heating rate of $10{ }^{\circ} \mathrm{C} / \mathrm{min}$ to determine glass transition temperature $T_{\mathrm{g}}$ and crystallization 
Table 1 Nomenclature of glass samples, their compositional distribution and glass transition temperature, DTA peak and density of various glass samples in the system $55\left[\left(\mathrm{~Pb}_{x} \mathrm{Bi}_{1-x}\right) \mathrm{TiO}_{3}\right]-44\left[2 \mathrm{SiO}_{2} \mathrm{~B}_{2} \mathrm{O}_{3}\right]-\mathrm{La}_{2} \mathrm{O}_{3}$

\begin{tabular}{|c|c|c|c|c|c|c|c|}
\hline \multirow{2}{*}{ Glass sample code } & \multirow{2}{*}{$x$} & \multicolumn{3}{|c|}{ Composition (wt\%) } & \multirow{2}{*}{$\begin{array}{c}\text { Glass transition } \\
\text { temperature } T_{\mathrm{g}}\left({ }^{\circ} \mathrm{C}\right)\end{array}$} & \multirow{2}{*}{$\begin{array}{c}\text { Crystallization } \\
\text { temperature } T_{\mathrm{c}}\left({ }^{\circ} \mathrm{C}\right)\end{array}$} & \multirow{2}{*}{$\begin{array}{l}\text { Density } \\
\left(\mathrm{g} / \mathrm{cm}^{3}\right) \\
\end{array}$} \\
\hline & & $\left(\mathrm{Pb}_{x} \mathrm{Bi}_{1-x}\right) \mathrm{TiO}_{3}$ & $2 \mathrm{SiO}_{2}-\mathrm{B}_{2} \mathrm{O}_{3}$ & $\mathrm{La}_{2} \mathrm{O}_{3}$ & & & \\
\hline BTL0.0 & 0.0 & 55 & 44 & 1 & 558 & 626 & 2.758 \\
\hline PBTL0.1 & 0.1 & 55 & 44 & 1 & 541 & 631 & 2.895 \\
\hline PBTL0.3 & 0.3 & 55 & 44 & 1 & 532 & 624 & 3.009 \\
\hline PBTL0.5 & 0.5 & 55 & 44 & 1 & 530 & 622 & 3.481 \\
\hline PBTL0.7 & 0.7 & 55 & 44 & 1 & 514 & $545,629,770$ & 3.972 \\
\hline
\end{tabular}

Table 2 Glass ceramic code, density, heating rate, holding time, holding temperature, crystal structure and crystalline phase

\begin{tabular}{|c|c|c|c|c|c|c|}
\hline \multirow{2}{*}{$\begin{array}{c}\text { Glass ceramic } \\
\text { code }\end{array}$} & \multirow{2}{*}{$\begin{array}{l}\text { Density } \\
\left(\mathrm{g} / \mathrm{cm}^{3}\right)\end{array}$} & \multicolumn{3}{|c|}{ Heat treatment schedule } & \multirow{2}{*}{$\begin{array}{l}\text { Crystal } \\
\text { structure }\end{array}$} & \multirow{2}{*}{$\begin{array}{c}\text { Crystalline } \\
\text { phase }\end{array}$} \\
\hline & & Heating rate $\left({ }^{\circ} \mathrm{C} / \mathrm{min}\right)$ & Holding time (h) & Holding temperature $\left({ }^{\circ} \mathrm{C}\right)$ & & \\
\hline BTL0.0626F & 2.765 & 5 & 4 & 626 & Cubic & BTO \\
\hline BTL0.0626E & 2.785 & 5 & 8 & 626 & Cubic & BTO \\
\hline PBTL0.1631F & 3.793 & 5 & 4 & 631 & Cubic & BTO \\
\hline PBTL0.1631E & 3.796 & 5 & 8 & 631 & Cubic & BTO \\
\hline PBTL0.3624F & 3.864 & 5 & 4 & 624 & Cubic & BTO \\
\hline PBTL0.3624E & 3.875 & 5 & 8 & 624 & Cubic & BTO \\
\hline PBTL0.5622F & 3.882 & 5 & 4 & 622 & Cubic & BTO \\
\hline PBTL0.5622E & 3.888 & 5 & 8 & 622 & Cubic & BTO \\
\hline PBTL0.7629F & 3.920 & 5 & 4 & 629 & Tetragonal & PBTO \\
\hline PBTL0.7629E & 3.941 & 5 & 8 & 629 & Tetragonal & РВТО \\
\hline PBTL0.7770F & 3.963 & 5 & 4 & 770 & Tetragonal & РBTO \\
\hline PBTL0.7770E & 3.998 & 5 & 8 & 770 & Tetragonal & PBTO \\
\hline
\end{tabular}

$\mathrm{BTO}-\mathrm{Bi}_{2} \mathrm{Ti}_{2} \mathrm{O}_{7}$ (bismuth titanum oxide); $\mathrm{PBTO}-\mathrm{Pb}_{3} \mathrm{Bi}_{4} \mathrm{Ti}_{6} \mathrm{O}_{21}$ (lead bismuth titanium oxide).

temperature $T_{\mathrm{c}}$. Sintered alumina was used as a reference material. On the basis of differential thermal analysis (DTA) results, various glass ceramic samples with compositions $x=0-0.5$ were prepared by heat treating the glasses in the temperature range of $622-631^{\circ} \mathrm{C}$ for $4 \mathrm{~h}$ and $8 \mathrm{~h}$. The different heat treatment schedules and nomenclature of glass ceramic samples are listed in Table 2.

\section{5 Nomenclature of glasses and glass ceramic samples}

Five-letter glass codes refer to the composition of the glasses. First three letters PBT designate the content of lead bismuth titanate. The fourth letter $\mathrm{L}$ indicates that $1 \mathrm{wt} \% \mathrm{La}_{2} \mathrm{O}_{3}$ is used as an additive, while the fifth letter, i.e., $0.0,0.1,0.3,0.5$ or 0.7 , indicates the fraction of $x$ in the glass system. For the nomenclature of the glass ceramic samples, the following methodology has been adopted. First five letters in the codes for the glass ceramic samples are similar to the codes of their parent glasses and refer to the composition of glasses, and the next three digits indicate the crystallization temperature. The last letter $F$ or $E$ refers to the holding time at crystallization temperature, $4 \mathrm{~h}$ and $8 \mathrm{~h}$ respectively. Take the glass ceramic sample PBTL0.1631F as an example: the first three letters represent the content of lead bismuth titanate, 0.1 represents the value of composition $(x=0.1), 631$ is the crystallization temperature and $\mathrm{F}$ indicates the $4 \mathrm{~h}$ soaking time. Phases were identified using powder XRD analysis. Diffraction patterns were recorded employing a Rigaku X-ray diffractometer using $\mathrm{Cu} \mathrm{K \alpha}$ radiation. The crystalline phases in each glass ceramic sample were identified by comparing its XRD pattern with standard patterns of various crystalline phases.

\section{6 Polishing for scanning electron microscopy and dielectric measurements}

The glass ceramic samples were ground and polished successively using SiC powders on a thick and flat glass plate. Finally polishing was carried out on a blazer cloth using diamond paste $(1 \mu \mathrm{m})$. The polished glass ceramic samples were etched for $1 \mathrm{~min}$ with a suitable etchant $\left(30 \% \mathrm{HNO}_{3}+20 \% \mathrm{HF}\right.$ solution). Etched surface of various glass ceramic samples was coated with gold by sputtering method. The samples 
were then examined using a JSM-840 scanning electron microscope (SEM) to study the morphology of different crystalline phases. Capacitance $(C)$ and dissipation factor $(D)$ were recorded as a function of temperature between room temperature and $500{ }^{\circ} \mathrm{C}$ at $0.1 \mathrm{kHz}, 1 \mathrm{kHz}, 10 \mathrm{kHz}$ and $1 \mathrm{MHz}$ using a Wayne Kerr $6500 \mathrm{P}$ (high frequency LCR meter, frequency $20 \mathrm{~Hz}-5 \mathrm{MHz}$ ). The values of capacitance $C$ and dissipation factor $D$ were measured as a function of frequency at various temperatures.

\section{Results and discussion}

\section{1 Density measurement analysis}

Density of all the glasses and glass ceramic samples is listed in Tables 1 and 2, respectively. A systematic trend is observed in the values of density for all the glass samples. From Table 1, it is observed that the density of the glass samples for all the compositions $(x=0-0.7)$ increases with increasing concentration of $\mathrm{PbO}$, because the density of $\mathrm{Pb}\left(11.4 \mathrm{~g} / \mathrm{cm}^{3}\right)$ is much greater than the density of $\mathrm{Bi}\left(9.8 \mathrm{~g} / \mathrm{cm}^{3}\right)$. The density of glass samples is found to lie in the range of $2.758-3.972 \mathrm{~g} / \mathrm{cm}^{3}$.

The measured density of the glass ceramic samples is listed in Table 2. It is observed that the density of the glass ceramic samples is found higher in comparison to the density of their parent glass samples. This is because during the crystallization or phase transformation change in volume results, it leads to a change in the specific gravity. The specific gravity of a glass ceramic is often different from that of the parent glass because of small volume changes that may occur during the heat treatment process. These changes may involve either a slight contraction or a slight expansion, but it would not usually exceed a $3 \%$ volume change. Hence the crystalline phases formed may have higher/lower densities than the original glass [36].

\subsection{X-ray diffraction analysis of glass samples}

Transparent bulk and thin glasses of optical quality with the composition $55\left[\left(\mathrm{~Pb}_{x} \mathrm{Bi}_{1-x}\right) \mathrm{TiO}_{3}\right]-$ $44\left[\left(2 \mathrm{SiO}_{2} \mathrm{~B}_{2} \mathrm{O}_{3}\right)\right]-\mathrm{La}_{2} \mathrm{O}_{3}(x=0-0.7)$ in molar ratio were synthesized via a conventional melt quenching technique. All XRD patterns of various glass samples BTL0.0, PBTL0.1, PBTL0.3, PBTL0.5 and PBTL0.7 are shown in Fig. 1. These XRD patterns exhibit broad diffuse scattering at different angles instead of crystalline peaks, confirming a long range structural disorder characteristic of amorphous glassy network.

\section{3 Differential thermal analysis}

DTA curves of prepared glasses with different lead to bismuth ratios $(x=0-0.7)$ are shown in Fig. 2. The DTA patterns of glasses with compositions $x=0-0.5$ show only one exothermic peak. These exothermic peaks represent the temperature at which the rate of crystallization of different phases is maximum. All glasses show a shift in the base line at different temperatures, depending on the compositions, in the temperature range of $514-558{ }^{\circ} \mathrm{C}$. These shifts in the base line show a change in the specific heat of the glasses, which is attributed to the glass transition temperature, $T_{\mathrm{g}}$ [37-40]. Glass transition temperatures of different glass samples are given in Table 1. The glass transition temperature has been found to decrease with decreasing concentration of $\mathrm{BiO}$. This may be due to increase in the viscosity of the melt. With decrease in $\mathrm{BiO}$ content in the glass samples, the glassy network forming oxide $\mathrm{SiO}_{2}$ reduces, and hence the viscosity of the glass and glass transition temperature $T_{\mathrm{g}}$ are decreased. It is reported by the previous researchers that with decreasing content of network-forming oxides, the glass transition temperatures are reduced. Due to the decrease of network-forming oxides in the glasses with the advent of bismuth titanate in the glasses, the viscosity and crosslinking are decreased [11]. The DTA pattern of the glass sample PBTL0.7 with composition $x=0.7$ shows three different peaks

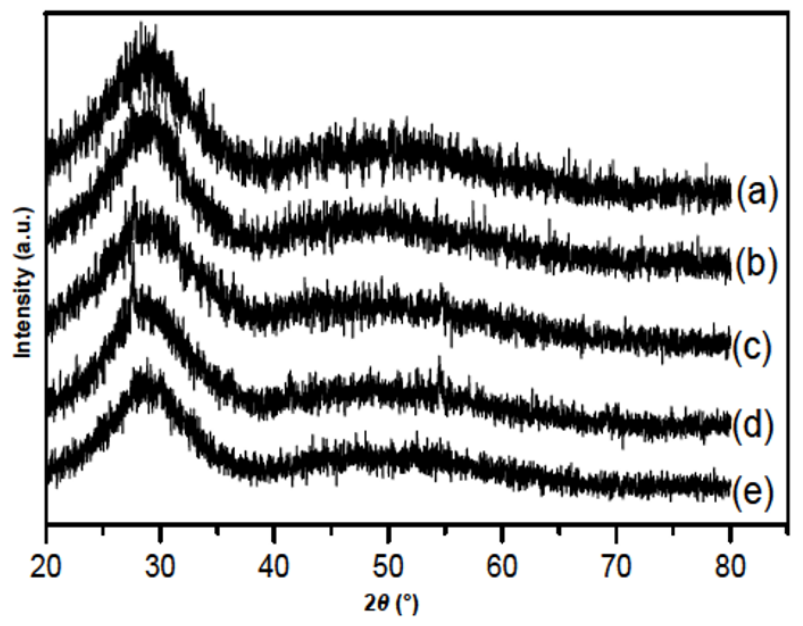

Fig. 1 XRD patterns of glass samples with (a) $x=0$, (b) $x=0.1$, (c) $x=0.3$, (d) $x=0.5$ and (e) $x=$ 0.7 in the glass system $55\left[\left(\mathrm{~Pb}_{x} \mathrm{Bi}_{1-x}\right) \mathrm{TiO}_{3}\right]-$ $44\left[2 \mathrm{SiO}_{2} \mathrm{~B}_{2} \mathrm{O}_{3}\right]-\mathrm{La}_{2} \mathrm{O}_{3}$. 


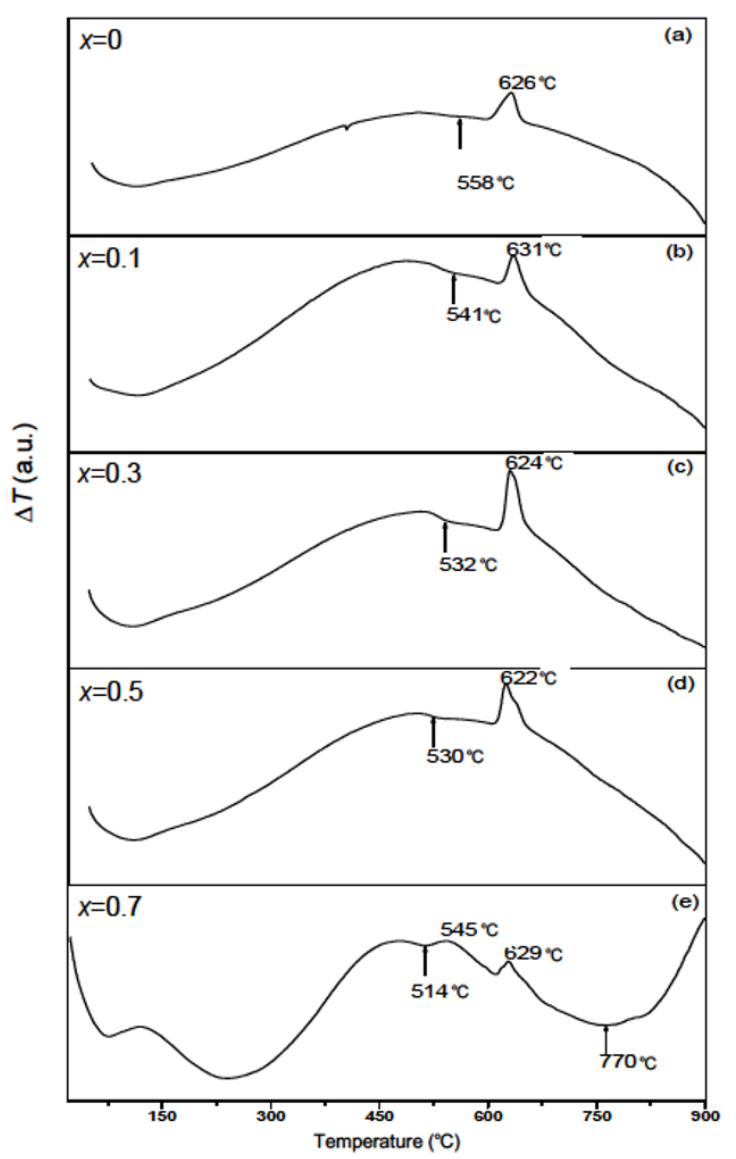

Fig. 2 DTA patterns of glass samples with (a) $x=0$, (b) $x=0.1$, (c) $x=0.3$, (d) $x=0.5$ and (e) $x=0.7$ in the glass system $55\left[\left(\mathrm{~Pb}_{x} \mathrm{Bi}_{1-x}\right) \mathrm{TiO}_{3}\right]-$ $44\left[2 \mathrm{SiO}_{2} \mathrm{~B}_{2} \mathrm{O}_{3}\right]-\mathrm{La}_{2} \mathrm{O}_{3}$.

$T_{\mathrm{c} 1}, T_{\mathrm{c} 2}$ and $T_{\mathrm{c} 3}$ at temperatures $545^{\circ} \mathrm{C}, 629^{\circ} \mathrm{C}$ and $770{ }^{\circ} \mathrm{C}$, respectively. The peaks at $T_{\mathrm{c} 1}$ and $T_{\mathrm{c} 2}$ are observed exothermic in nature while the peak at $T_{\mathrm{c} 3}$ is endothermic (Fig. 2(e)). The peak at $T_{\mathrm{c} 1}$ for glass compositions $x=0-0.5$ represents the crystallization of the major bismuth titanium oxide $\left(\mathrm{Bi}_{2} \mathrm{Ti}_{2} \mathrm{O}_{7}\right)$ phase in all the glass ceramic samples. The DTA pattern of glass sample for $x=0.7$ (Fig. 2(e)) shows the peak at $545{ }^{\circ} \mathrm{C}$ due to some volatile impurity in the glass sample, not due to the crystallization of the major/minor phases, while the peaks at $629^{\circ} \mathrm{C}$ and $770{ }^{\circ} \mathrm{C}$ are due to the crystallization of the $\mathrm{Bi}_{2} \mathrm{Ti}_{2} \mathrm{O}_{7}$ (bismuth titanum oxide) $/ \mathrm{Pb}_{3} \mathrm{Bi}_{4} \mathrm{Ti}_{6} \mathrm{O}_{21}$ (lead bismuth titanium oxide) phases. This is also confirmed by powder XRD studies that the peaks correspond to the crystallization of major phases of all the glasses.

\section{4 X-ray diffraction analysis and crystallization behavior}

XRD patterns for various glass ceramic samples crystallized at different temperatures with a heating rate of $5{ }^{\circ} \mathrm{C} / \mathrm{min}$ for $4 \mathrm{~h}$ are shown in Fig. 3. All the peaks in respective XRD patterns are matched with

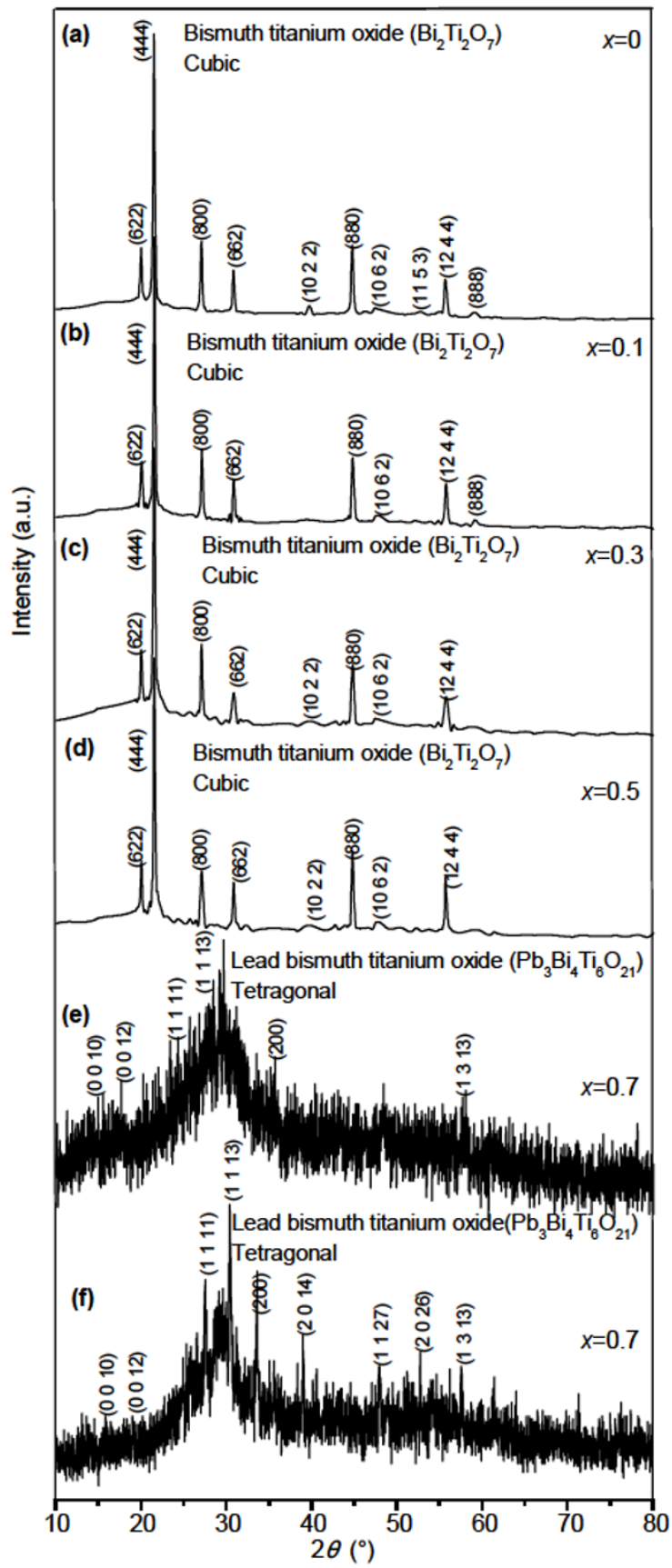

Fig. $3 \mathrm{XRD}$ patterns of different glass ceramic samples: (a) BTL0.0626F, (b) PBTL0.1631F, (c) PBTL0.3624F, (d) PBTL0.5622F, (e) PBTL0.7629F and (f) PBTL0.7770F. 
JCPDS Cards Nos. 32-0118 and 35-0007 of various compounds of constituent oxides. XRD pattern for the glass ceramic sample BTL0.0626F $(x=0)$ is shown in Fig. 3(a). It is observed from the XRD pattern that bismuth titanium oxide $\left(\mathrm{Bi}_{2} \mathrm{Ti}_{2} \mathrm{O}_{7}, \mathrm{BTO}\right)$ is the major crystalline phase for this glass ceramic sample. Figures 3(b) and 3(c) show the XRD patterns of glass ceramic samples PBTL0.1631F and PBTL0.3624F heat treated at different temperatures. The XRD pattern of glass ceramic sample PBTL0.1631F shows the presence of cubic phase of $\mathrm{Bi}_{2} \mathrm{Ti}_{2} \mathrm{O}_{7}$ as a major phase. The XRD data of the major phase of glass ceramic samples rich in bismuth content $(x=0-0.5)$ and glass ceramic samples rich in lead content $(x=0.7)$ are indexed on the basis of cubic as well as tetragonal unit cells. Glass ceramic code, density, heating rate, holding time, holding temperature, crystal structure and crystalline phase are given in Table 2 . The glass ceramic sample with $x=0.5$ obtained by the heat treatment at $622{ }^{\circ} \mathrm{C}$ is found to show the similar crystallization behavior of glass ceramic sample PBTL0.3624F (Fig. 3(c)), differing slightly only in terms of peak intensity and values of $2 \theta$. The XRD patterns of glass ceramic samples PBTL0.7629F and PBTL0.7770F are shown in Figs.3(e) and 3(f), respectively. The XRD patterns of these glass ceramic samples show the presence of tetragonal major phase of lead bismuth titanium oxide $\left(\mathrm{Pb}_{3} \mathrm{Bi}_{4} \mathrm{Ti}_{6} \mathrm{O}_{21}, \mathrm{PBTO}\right)$. Improved crystanality has been observed in the glass ceramic sample which is obtained by heat treating at $770{ }^{\circ} \mathrm{C}$ (PBTL0.7770F) in comparison to the glass ceramic sample obtained by heat treating at $629{ }^{\circ} \mathrm{C}$ (PBTL0.7629F). The crystallite size was calculated using Scherer formula [41]:

$$
D_{\mathrm{p}}=\frac{K \lambda}{\beta \cos \theta}
$$

where $K$ is the shape factor (0.94); $\lambda$ is the wavelength of $\mathrm{Cu} \mathrm{K} \alpha$ line (1.54 $\AA$ ); and $\beta$ is the full width at half maximum. Glass ceramic sample code, average crystallite and grain size have been listed in Table 3 . The minimum and maximum values of crystallite size corresponding to maximum intensity peaks of glass ceramic samples PBTL0.7629F and PBTL0.5622E have been found $1.10 \mathrm{~nm}$ and $66.09 \mathrm{~nm}$, and their average crystallite size are $833 \mathrm{~nm}$ and $500 \mathrm{~nm}$, respectively.

The XRD patterns for glass ceramic samples BTL0.0626E, PBTL0.1631E, PBTL0.3624E, PBTL0.5622E, PBTL0.7629E and PBTL0.7770E are
Table 3 Glass ceramic sample code, average crystallite and grain size

\begin{tabular}{ccc}
\hline $\begin{array}{c}\text { Glass ceramic sample } \\
\text { code }\end{array}$ & $\begin{array}{c}\text { Crystallite size } \\
\text { (nm) }\end{array}$ & $\begin{array}{c}\text { Grain size } \\
\text { (nm) }\end{array}$ \\
\hline BTL0.0626F & 43.48 & 1250 \\
BTL0.0626E & 38.01 & 600 \\
PBTL0.1631F & 50.75 & 1250 \\
PBTL0.1631E & 60.93 & 500 \\
PBTL0.3624F & 30.43 & 500 \\
PBTL0.3624E & 27.67 & 750 \\
PBTL0.5622F & 50.75 & 1000 \\
PBTL0.5622E & 66.09 & 500 \\
PBTL0.7629F & 1.10 & 833 \\
PBTL0.7629E & 1.25 & 1250 \\
PBTL0.7770F & 2.51 & 1250 \\
PBTL0.7770E & 2.87 & 1250 \\
\hline
\end{tabular}

shown in Fig. 4. Glass ceramic samples BTL0.0626E and PBTL0.1631E have the phase constitution similar to BTL0.0626F and PBTL0.1631F that obtained by heat treating for $4 \mathrm{~h}$. For the glass ceramic sample PBTL0.3624E, a change is observed in the crystalline nature in the XRD pattern of this glass ceramic sample in comparison to the glass ceramic sample PBTL 0.3624F. This change may be due to back ground noise and a new peak observed at $2 \theta$ value $14.8^{\circ}$ corresponding to the plane (222). Similar crystallization behavior has been observed for glass ceramic sample PBTL0.5622E (Fig. 4(d)). The major phase of lead bismuth titanium oxide $\left(\mathrm{Pb}_{3} \mathrm{Bi}_{4} \mathrm{Ti}_{6} \mathrm{O}_{21}\right.$, PBTO) is crystallized for the glass sample heat treated at $629^{\circ} \mathrm{C}$ for $8 \mathrm{~h}$. Further, for the same glass sample crystallized at $770{ }^{\circ} \mathrm{C}$ for $8 \mathrm{~h}$ heat treatment schedule, the major phase of PBTO crystallizes successfully; only a slight change has been observed in the XRD pattern of this glass ceramic sample in which broadness of the peak decreases showing the decrement in the amorphous nature of the glass ceramic sample. The XRD patterns of these glass ceramic samples crystallized for $4 \mathrm{~h}$ as well as $8 \mathrm{~h}$ heat treatment schedules along with SEM micrographs give adequate information about the morphology and crystallites size.

\section{5 Surface morphological analysis}

The surface morphology of all glass ceramic samples shows fine crystallites of major phases of bismuth titanum oxide $\left(\mathrm{Bi}_{2} \mathrm{Ti}_{2} \mathrm{O}_{7}, \mathrm{BTO}\right)$ and lead bismuth titanium oxide $\left(\mathrm{Pb}_{3} \mathrm{Bi}_{4} \mathrm{Ti}_{6} \mathrm{O}_{21}, \mathrm{PBTO}\right)$. Qualitative inspection of all these SEM micrographs reveals that the relative content of residual glass phase is present in 


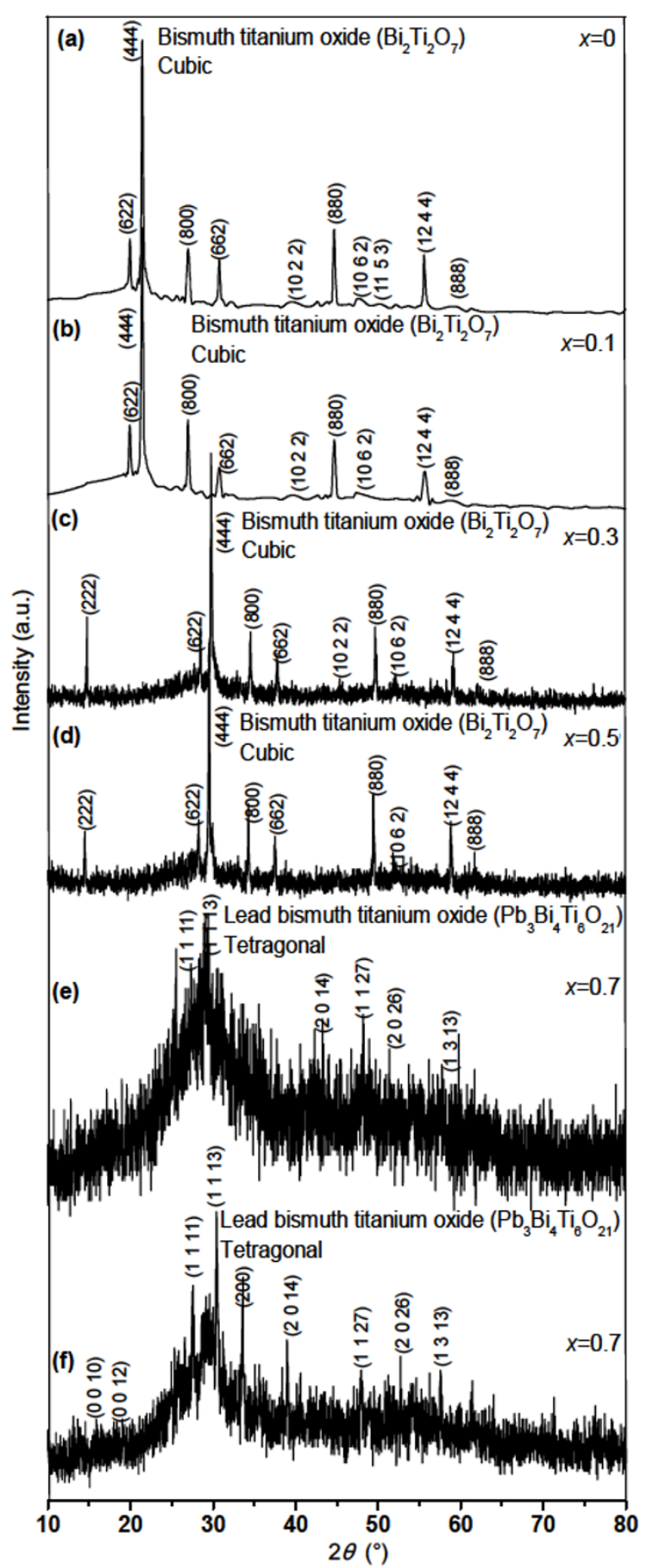

Fig. 4 XRD patterns of different glass ceramic samples: (a) BTL0.0626E, (b) PBTL0.1631E, (c) PBTL0.3624E, (d) PBTL0.5622E, (e) PBTL0.7629E and (f) PBTL0.7770E.

little amount or absent significantly in bismuth rich glass ceramic samples. The coexistence of coarse and fine particles has been also observed in all the glass ceramic sample micrographs similar to the lead titanate based glass-ceramics $[42,43]$. The SEM micrographs of various glass ceramic samples heat treated for $4 \mathrm{~h}$ and $8 \mathrm{~h}$ are shown in Figs. 5-7. Figure 5 shows SEM micrographs of glass ceramic samples BTL0.0626F, PBTL0.1631F, PBTL0.3624F, PBTL0.5622F, PBTL $0.7629 \mathrm{~F}$ and PBTL $0.7770 \mathrm{~F}$. The glass ceramic sample BTL0.0626F is found to be composed of interconnected fine and uniform crystallites of bismuth titanum oxide $\left(\mathrm{Bi}_{2} \mathrm{Ti}_{2} \mathrm{O}_{7}, \mathrm{BTO}\right)$, which are dispersed in the glassy matrix and separated by well developed grain boundaries throughout the micrograph (Fig. 5(a)). XRD studies confirm that the fine crystallites are BTO which is the major crystalline phase. In general, the white region in the microstructure represents the agglomerated major crystalline phase of BTO, while the black region depicts the residual glass in all SEM micrographs. For the glass ceramic sample PBTL0.1631F, there is a change in the morphology of the crystallites of the major phase BTO (Fig. 5(b)). These crystallites are found to have irregular shape and not uniformly distributed in the glassy matrix. Figure 5(c) shows the SEM micrograph of the glass ceramic sample PBTL0.3624F. The crystallite size has been found in the order of sub-micron range, while the volume fraction of the residual glass has been found large. The crystal growth and their distribution are not appearing properly in this micrograph. Figure 5(d) represents the SEM micrograph for the glass ceramic sample PBTL0.5622F. The glass ceramic sample PBTL $0.5622 \mathrm{~F}$ shows the cabbage-like crystallites are uniformly dispersed as a major phase of BTO along with trace amount of secondary phase in the glassy matrix.

Figures 5(e) and 5(f) depict the SEM micrographs for the glass ceramic samples PBTL0.7629F and PBTL $0.7770 \mathrm{~F}$, respectively. Tetragonal lead bismuth titanium oxide $\left(\mathrm{Pb}_{3} \mathrm{Bi}_{4} \mathrm{Ti}_{6} \mathrm{O}_{21}\right)$ is crystallized as the major phase for these glass ceramic samples. There are two types of phase formation seen in these micrographs: (i) tetragonal crystallites which are big in shape and size due to the large content of $\mathrm{PbO}(x=0.7)$ and (ii) needle-like secondary phase due to the crystal growth of the bismuth oxide. When the same glass sample is crystallized at higher temperature $770{ }^{\circ} \mathrm{C}$, a slight change in the morphology has been found that the needle-like secondary phase is observed very less.

Figure 6 shows the SEM micrographs of different glass ceramic samples BTL0.0626E, PBTL0.1631E, PBTL0.3624E and PBTL0.3624E (at lower magnification). These glass ceramic samples are obtained through crystallization of their parent glasses for $8 \mathrm{~h}$ heat treatment schedule. The entire morphology 

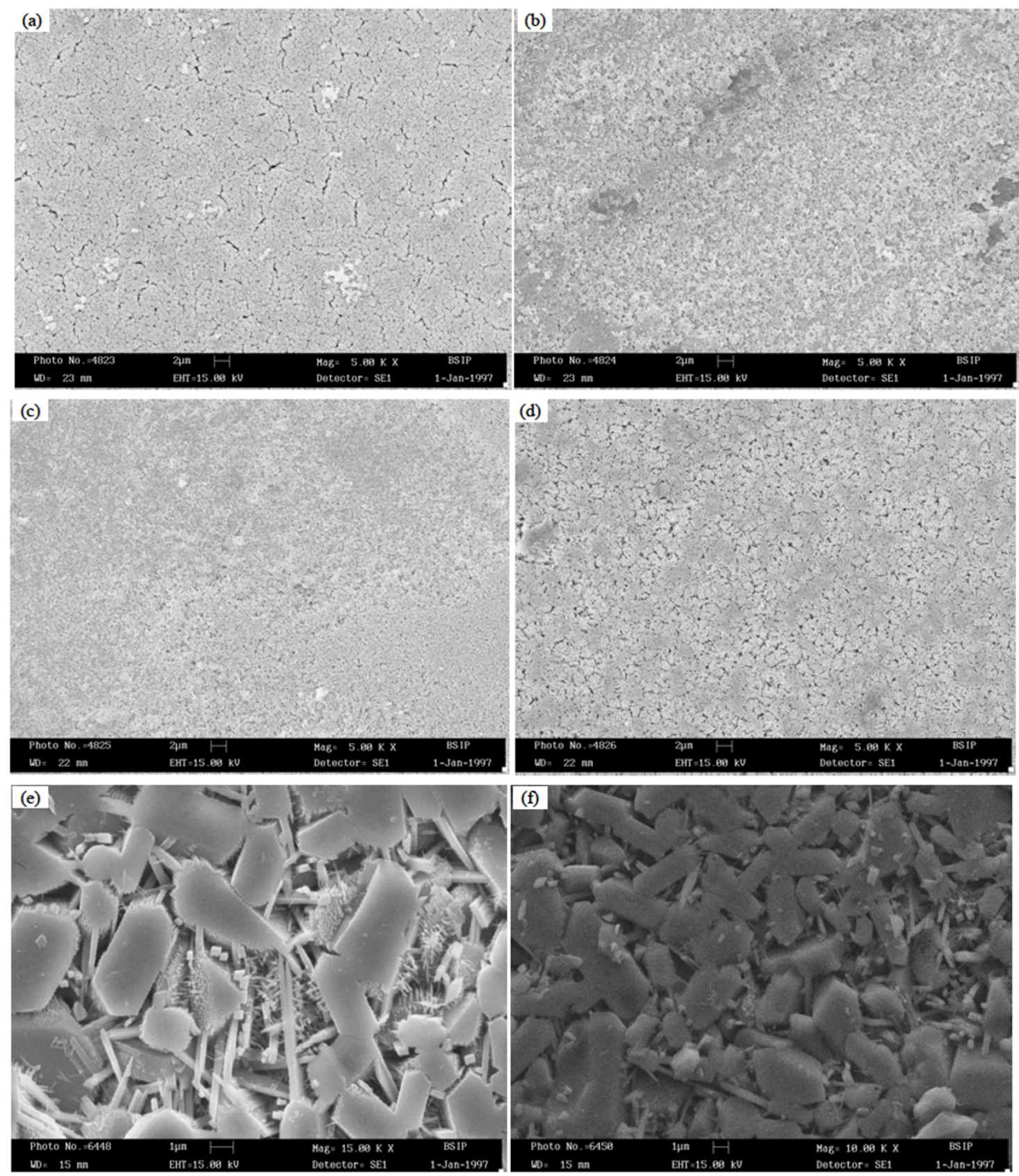

Fig. 5 SEM micrographs of glass ceramic samples: (a) BTL0.0626F, (b) PBTL0.1631F, (c) PBTL0.3624F, (d) PBTL0.5622F, (e) PBTL0.7629F and (f) PBTL0.7770F.

has been found to be changed in comparison to the $4 \mathrm{~h}$ heat treated glass ceramic samples with the same compositions, which are not clear from XRD studies. Figures 6(a) and 6(b) depict the SEM micrographs of the glass ceramic samples BTL0.0626E and PBTL0.1631E. The morphology of the crystallites is found similar, but they are differing in terms of the crystal growth and their distribution. The well developed, interconnected and dense crystallites of the major phase of BTO are dispersed uniformly in the glassy matrix, while the crystal growth for the glass ceramic sample PBTL0.1631E $(x=0.1)$ are not well developed and the agglomeration of the crystallites are also observed. Figures 6(c) and 6(d) show the micrographs of the glass ceramic sample PBTL 0.3624E at different magnifications. Very sharp and fine needle-like crystal growth of major phase of BTO has been observed along with secondary phase. When we take the micrograph of the same glass ceramic sample PBTL0.3624E at lower magnification, the secondary phase is clearly seen in different shape and size. 

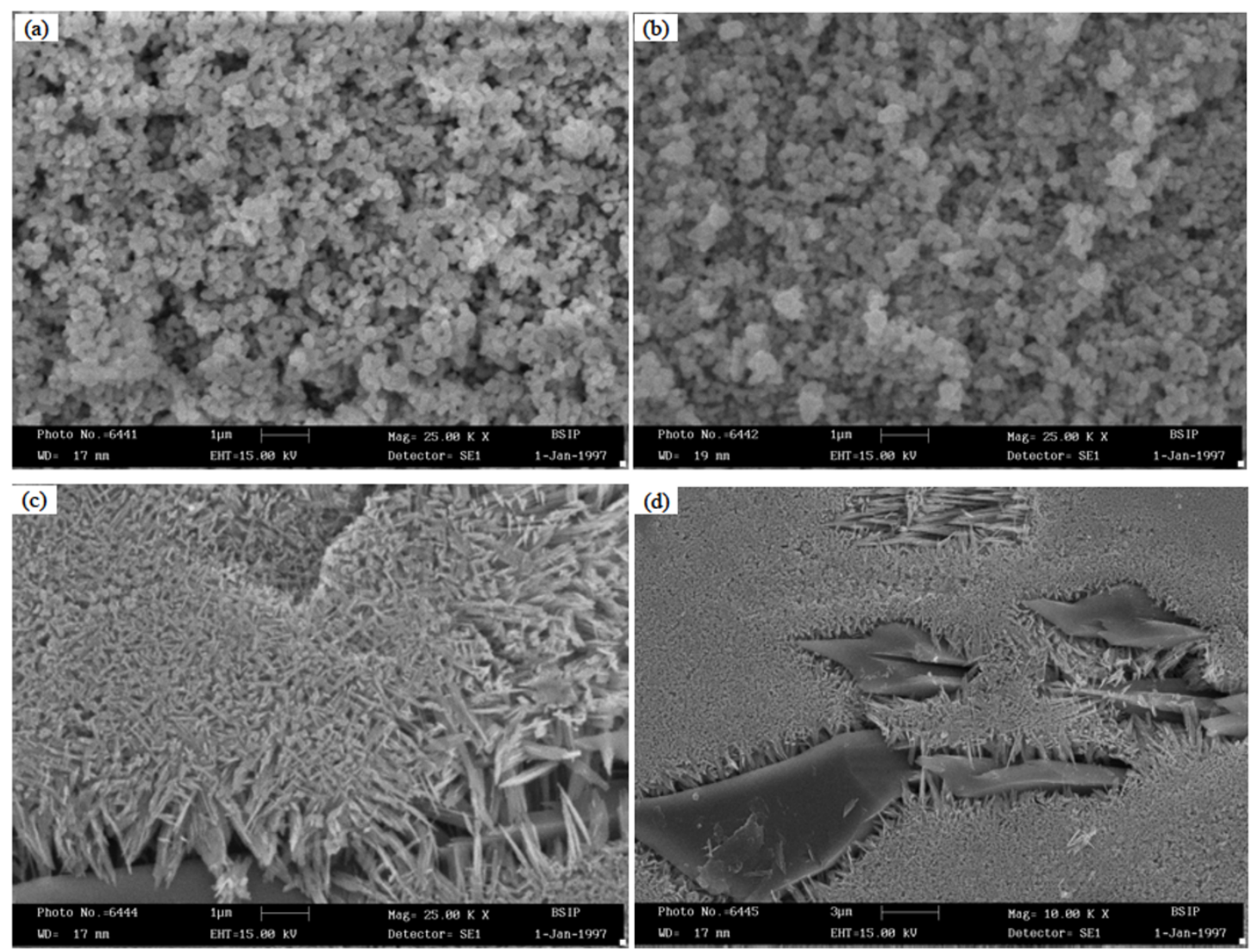

Fig. 6 SEM micrographs of glass ceramic samples: (a) BTL0.0626E, (b) PBTL0.1631E, (c) PBTL 0.3624E and (d) PBTL0.3624E (at lower magnification).

Figure 7 shows the SEM of glass ceramic samples PBTL0.5622E, PBTL0.7629E, and PBTL0.770E respectively. Figure 7(a) represents the micrograph of the glass ceramic sample PBTL0.5622E which is obtained by $8 \mathrm{~h}$ heat treatment schedule of the same parent glass sample. Very fine crystal growth has been observed along with needle-like secondary phase. If we compare this micrograph with $4 \mathrm{~h}$ heat treated glass ceramic sample (Fig. 5(d)), the grain boundary seems to be disappearing and interconnected to each other for $8 \mathrm{~h}$ heat treated glass ceramic sample. Figures $7(\mathrm{c})$ and 7 (d) show the similar morphology of the glass ceramic samples heat treated for $4 \mathrm{~h}$.

\section{6 Dielectric behavior}

Dielectric constant $\varepsilon_{\mathrm{r}}$ and dissipation factor $D$ were measured as a function of temperature within the temperature range of $50-320^{\circ} \mathrm{C}$ at various selected frequencies such as $20 \mathrm{~Hz}$ to $1.0 \mathrm{MHz}$ for tentative glass ceramic samples PBTL0.3624F and PBTL $0.5622 \mathrm{~F}$. Figure 8 shows the variations of $\varepsilon_{\mathrm{r}}$ and $D$ with temperature for glass ceramic sample PBTL $0.3624 \mathrm{~F}$. Initially, the value of $\varepsilon_{\mathrm{r}}$ has been found constant up to a certain value of temperature $200{ }^{\circ} \mathrm{C}$, and thereafter, it increases with increasing temperature at low frequency range from $20 \mathrm{~Hz}$ to $1 \mathrm{kHz}$, while the value of $\varepsilon_{\mathrm{r}}$ is found constant meaning temperature independent at the high frequency range. The value of dielectric constant $\varepsilon_{\mathrm{r}}$ and dissipation factor $D$ at temperature $60^{\circ} \mathrm{C}$ at $1 \mathrm{kHz}$ have been found to be 32 and 0.0013 , respectively. Almost similar behavior has been observed for the plot of dissipation factor $D$ vs. temperature. The maximum value of dielectric constant is found to be the order of 500 along with dissipation factor value 1.2 .

Figure 9 shows the plots of dielectric constant $\varepsilon_{\mathrm{r}}$ and dissipation factor $D$ vs. temperature for the glass ceramic sample PBTL0.5622F. Both the plots has similar trends and increase in $\varepsilon_{\mathrm{I}}$ and $D$, which may be due to increase in the electrical conduction with increasing temperature [44]. The dielectric behavior of this glass ceramic sample can be explained in terms of the addition of $\mathrm{La}_{2} \mathrm{O}_{3}$ which promotes the crystallization of the glass during the heat treatment. A small concentration of donor dopant $\mathrm{La}^{3+}$ in perovskite ceramics is known to induce an n-type 


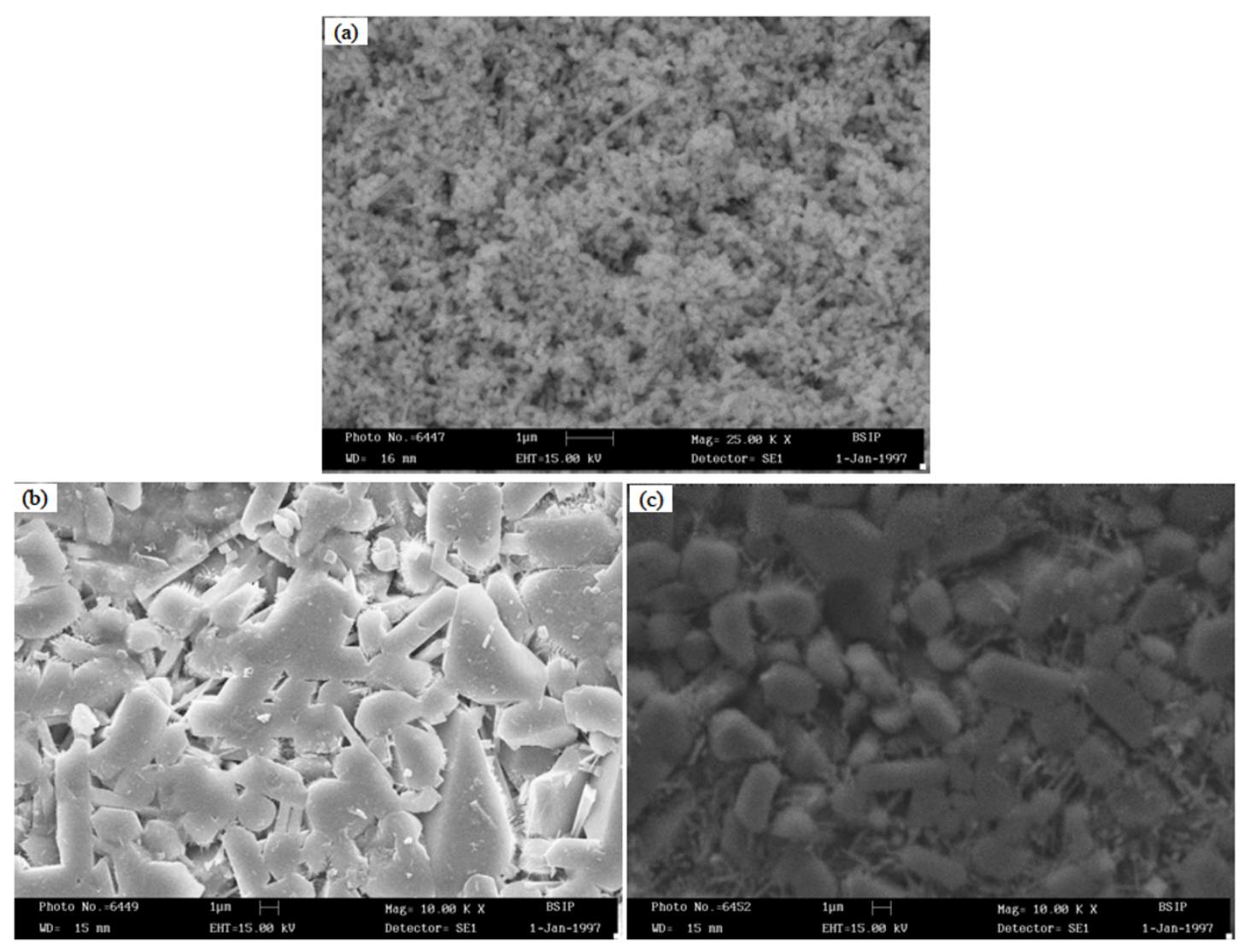

Fig. 7 SEM micrographs of glass ceramic samples: (a) PBTL0.5622E, (b) PBTL0.7629E and (c) PBTL0.770E.

semiconductivity by electronic compensation.

$$
\mathrm{La}^{3+} \stackrel{\mathrm{BiTi}_{3}}{\longrightarrow} \mathrm{La}_{\mathrm{Sr}}+\mathrm{e}^{\prime}
$$

Due to the difference in conductivity, interfacial polarization arises at crystal-glass interface and attributes to high value of dielectric constant $\varepsilon_{\mathrm{r}}$. This causes the effective value of $\varepsilon_{\mathrm{T}}$ with the order of 1100 [45]. The increase in the value of dielectric constant with increasing temperature at $0.1 \mathrm{kHz}$ to $1 \mathrm{kHz}$ for these glass ceramic samples might be due to the increasing concentration of $\mathrm{Bi}^{2+}$ in the parent glass compositions. The dielectric constant as well as loss data shows that with increasing value of $x$ (content of $\mathrm{PbO})$ in the glasses, $\varepsilon_{\mathrm{r}}$ and loss values are increased gradually. This increase in $\varepsilon_{\mathrm{r}}$ and $D$ values is attributed to the expending concentration of alkali ion charge carriers with increase of $\mathrm{PbO}$ content in the glass in expense of $\mathrm{SiO}_{2}$. Electrical property of a glass is primarily controlled by the connectivity of the continuous glassy phase, and this glass phase is reduced and crystalline phases are increased after heat treatment. It is observed that glass ceramic sample PBTL $0.5622 \mathrm{~F}$ contains less crystal compared to the glass ceramic sample PBTL0.3624F, and its dielectric loss is more compared to PBTL0.5622F. Murugan et al. [2] have also observed that the dielectric loss $D$ decreases with increasing ferroelectric phases in the glass-ceramics, and they also reported that $D$ value is less for glasses compared to the polycrystalline ceramics in the same system.

\section{Conclusions}

DTA patterns of the Bi rich glass samples show only single exothermic peak, while DTA patterns of the $\mathrm{Pb}$ rich glass samples show more than one exothermic peak as well as one endothermic peak. DTA peak at $T_{\mathrm{c}}$ for all glass samples shifts towards lower temperature side due to the different melting temperature and viscosity of the melts. The XRD patterns of Bi rich glass ceramic samples show the major phase of bismuth titanum oxide $\left(\mathrm{Bi}_{2} \mathrm{Ti}_{2} \mathrm{O}_{7}\right)$, while it is observed for $\mathrm{Pb}$ rich glass ceramic samples as lead bismuth titanium oxide $\left(\mathrm{Pb}_{3} \mathrm{Bi}_{4} \mathrm{Ti}_{6} \mathrm{O}_{21}\right)$. Crystalline phase of all the glass ceramic samples with $0 \leqslant x \leqslant 0.5$ is found to have cubic crystal structure, and for $x=0.7$ it is observed tetragonal crystal structure. The effect of heat 

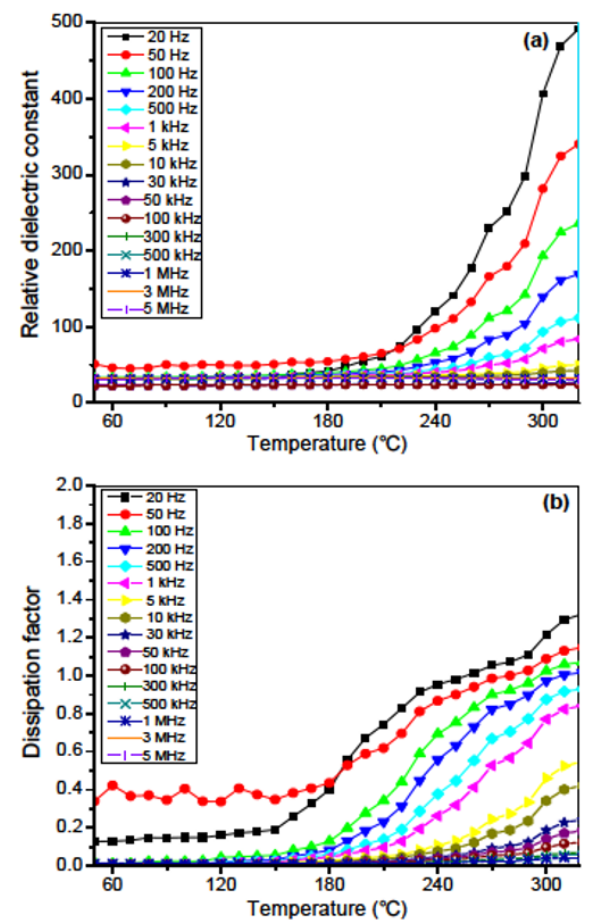

Fig. 8 Variations of (a) dielectric constant $\varepsilon_{\mathrm{r}}$ and (b) dissipation factor $D$ with temperature at different frequencies for the glass ceramic sample PBTL0.3624F.
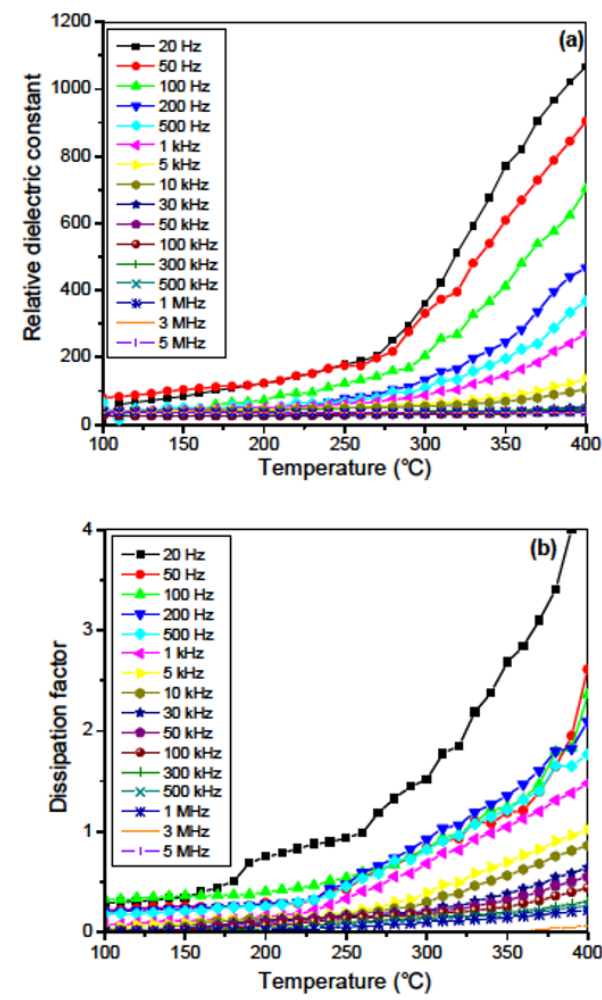

Fig. 9 Variations of (a) dielectric constant $\varepsilon_{\mathrm{r}}$ and (b) dissipation factor $D$ with temperature at different frequencies for the glass ceramic sample PBTL0.5622F. treatment schedule for $4 \mathrm{~h}$ and $8 \mathrm{~h}$ changes the surface morphology of the crystallites. XRD results reveal that the heat treatment schedules are found to be the same for $4 \mathrm{~h}$ and $8 \mathrm{~h}$. It is also concluded that the value of dielectric constant is found larger for glass ceramic sample PBTL0.5622F in comparison to the glass ceramic sample PBTL0.3624F.

\section{Acknowledgements}

The authors are gratefully acknowledged to the Uttar Pradesh Council of Science and Technology, Lucknow (India) for financial support under the "Young Scientist Scheme" as major research project No. CSTT/YSS/D3913. Authors are also thankful to Dr. Atul Khanna, associate professor, for his constant support and to extending the XRD measurement facility at Department of Physics, Guru Nanak Dev University, Amritsar 143005 , India.

Open Access: This article is distributed under the terms of the Creative Commons Attribution License which permits any use, distribution, and reproduction in any medium, provided the original author(s) and the source are credited.

\section{References}

[1] Aurivillius B. Mixed bismuth oxides with layer lattices. II. Structure of $\mathrm{Bi}_{4} \mathrm{Ti}_{3} \mathrm{O}_{12}$. Arkiv for Kemi 1949, 1: 499-512.

[2] Murugan GS, Subbanna GN, Varma KBR. Nanocrystallization of ferroelectrics bismuth tungstate in lithium borate glass matrix. J Mater Sci Lett 1999, 18: 1687-1690.

[3] Borrelli NF, Layton MM. Electrooptic properties of transparent ferroelectric glass-ceramic systems. IEEE T Electron Dev 1969, 16: 511-514.

[4] Bell AJ. Ferroelectrics: The role of ceramic science and engineering. $J$ Eur Ceram Soc 2008, 28: 1307-1317.

[5] Pengpat K, Holland D. Ferroelectric glass-ceramics from the $\mathrm{PbO}-\mathrm{GeO}_{2}-\mathrm{Nb}_{2} \mathrm{O}_{5}$ system. $J$ Eur Ceram Soc 2004, 24: 2951-2958.

[6] Graça MPF, da Silva MGF, Valente MA. Structural and electrical properties of $\mathrm{SiO}_{2}-\mathrm{Li}_{2} \mathrm{O}-\mathrm{Nb}_{2} \mathrm{O}_{5}$ glass and glass-ceramics obtained by thermoelectric treatments. J Mater Sci 2007, 42: 2543-2550.

[7] Graça MPF, Valente MA, da Silva MGF. The electric behavior of a lithium-niobate-phosphate glass and glass-ceramics. J Mater Sci 2006, 41: 1137-1141. 
[8] Shankar MV, Varma KBR. Crystallization of ferroelectric bismuth vanadate in $\mathrm{Bi}_{2} \mathrm{O}_{3}-\mathrm{V}_{2} \mathrm{O}_{5}$ $\mathrm{SrB}_{4} \mathrm{O}_{7}$ glasses. J Non-Cryst Solids 1998, 226: 145-154.

[9] Pengpat K, Holland D. Glass-ceramics containing ferroelectric bismuth germanate $\left(\mathrm{Bi}_{2} \mathrm{GeO}_{5}\right)$. J Eur Ceram Soc 2003, 23: 1599-1607.

[10] Ruiz-Valdés JJ, Gorokhovsky AV, Escalante-García $\mathrm{J}$, et al. Glass-ceramic materials with regulated dielectric properties based on the system $\mathrm{BaO}-\mathrm{PbO}-$ $\mathrm{TiO}_{2}-\mathrm{B}_{2} \mathrm{O}_{3}-\mathrm{Al}_{2} \mathrm{O}_{3}$. J Eur Ceram Soc 2004, 24: 1505-1508.

[11] Bengisu M, Brow RK, Wittenauer A. Glasses and glass-ceramics in the $\mathrm{SrO}-\mathrm{TiO}_{2}-\mathrm{Al}_{2} \mathrm{O}_{3}-\mathrm{SiO}_{2}-\mathrm{B}_{2} \mathrm{O}_{3}$ system and the effect of $\mathrm{P}_{2} \mathrm{O}_{5}$ additions. J Mater Sci 2008, 43: 3531-3538.

[12] Subbarao EC. A family of ferroelectric bismuth compounds. J Phys Chem Solids 1962, 23: 665-676.

[13] De Araujo CA, Cuchiaro J, Mcmillan LD, et al. Fatigue-free ferroelectric capacitors with platinum electrodes. Nature 1994, 374: 627-629.

[14] Park BH, Kang BS, Bu SD, et al. Lanthanumsubstituted bismuth titanate for use in non-volatile memories. Nature 1999, 401: 682-684.

[15] Takenaka T, Nagata H. Current status and prospects of lead-free piezoelectric ceramics. J Eur Ceram Soc 2005, 25: 2693-2700.

[16] Kojima S, Hushur A, Jiang F, et al. Crystallization of amorphous bismuth titanate. J Non-Cryst Solids 2001, 293-295: 250-254.

[17] Sunahara K, Yano J, Kakegawa K. Preparation of $\mathrm{Bi}_{4} \mathrm{Ti}_{3} \mathrm{O}_{12}$ particles by crystallization from glass. J Eur Ceram Soc 2006, 26: 623-626.

[18] Gerth K, Rüssel C. Crystallization of $\mathrm{Bi}_{4} \mathrm{Ti}_{3} \mathrm{O}_{12}$ from glasses in the system $\mathrm{Bi}_{2} \mathrm{O}_{3} / \mathrm{TiO}_{2} / \mathrm{B}_{2} \mathrm{O}_{3}$. J Non-Cryst Solids 1997, 221: 10-17.

[19] Bruton TM. Study of the liquidus in the system $\mathrm{Bi}_{2} \mathrm{O}_{3}-\mathrm{TiO}_{2}$. J Solid State Chem 1974, 9: 173-175.

[20] Gerth K, Rüssel C. Crystallization of $\mathrm{Bi}_{3} \mathrm{TiNbO}_{9}$ from glasses in the system $\mathrm{Bi}_{2} \mathrm{O}_{3} / \mathrm{TiO}_{2} / \mathrm{Nb}_{2} \mathrm{O}_{5} / \mathrm{B}_{2} \mathrm{O}_{3} /$ $\mathrm{SiO}_{2}$. J Non-Cryst Solids 1999, 243: 52-60.

[21] Krapchanska M, Dimitriev Y, Iordanova R. Phase formation in the system $\mathrm{Bi}_{2} \mathrm{O}_{3}-\mathrm{TiO}_{2}-\mathrm{SiO}_{2}$. Journal of the University of Chemical Technology and Metallurgy 2006, 41: 307-310.

[22] Tang Q-Y, Kan Y-M, Wang P-L, et al. Nd/V co-doped $\mathrm{Bi}_{4} \mathrm{Ti}_{3} \mathrm{O}_{12}$ power prepared by molten salt synthesis. J Am Ceram Soc 2007, 90: 3353-3356.

[23] Kojima $\mathrm{T}$, Sakai $\mathrm{T}$, Watanabe $\mathrm{T}$, et al. Large remanent polarization of $(\mathrm{Bi}, \mathrm{Nd})_{4} \mathrm{Ti}_{3} \mathrm{O}_{12}$ epitaxial thin films grown by metalorganic chemical vapor deposition. Appl Phys Lett 2002, 80: 2746.
[24] Kim JK, Kim SS, Kim W-J. Effects of annealing conditions on the electrical properties of $\mathrm{Bi}_{4-x} \mathrm{Nd}_{x} \mathrm{Ti}_{3} \mathrm{O}_{12}(x=0.46)$ thin films processed at low temperature. Appl Phys A 2006, 82: 737-740.

[25] Sakamoto W, Yamada M, Iizawa N, et al. Preparation and properties of $\mathrm{Bi}_{4-x} \mathrm{Nd}_{x} \mathrm{Ti}_{3} \mathrm{O}_{12}$ thin films by chemical solution deposition. J Electroceram 2004, 13: 339-343.

[26] Wu D, Li A, Ming N. Structure and electrical properties of of $\mathrm{Bi}_{3.15} \mathrm{Nd}_{0.85} \mathrm{Ti}_{3} \mathrm{O}_{12}$ ferroelectric thin films. J Appl Phys 2004, 95: 4275.

[27] Maiwa $\mathrm{H}$, Iizawa $\mathrm{N}$, Togawa $\mathrm{D}$, et al. Electromechanical properties of Nd-doped $\mathrm{Bi}_{4} \mathrm{Ti}_{3} \mathrm{O}_{12}$ films: A candidate for lead-free thin-film piezoelectics. Appl Phys Lett 2003, 82: 1760-1762.

[28] Suyal G, Bharadwaja SSN, Cantoni M, et al. Properties of chemical solution deposited polycrystalline neobidium-modified $\mathrm{Bi}_{4} \mathrm{Ti}_{3} \mathrm{O}_{12}$. J Electroceram 2002, 9: 187-192.

[29] Gao XS, Xue JM, Wang J. Ferroelectric behavior and charge carriers in $\mathrm{Nd}$-doped $\mathrm{Bi}_{4} \mathrm{Ti}_{3} \mathrm{O}_{12}$ thin films. J Appl Phys 2005, 97: 034101.

[30] Chen M, Liu ZL, Wang Y, et al. Ferroelectric properties and microstructures of $\mathrm{Nd}_{2} \mathrm{O}_{3}$-doped $\mathrm{Bi}_{4} \mathrm{Ti}_{3} \mathrm{O}_{12}$ ceramics. Phys Status Solidi a 2003, 200: 446-450.

[31] Vernacotala DE, Chatlani S, Shelby JE. Applications of ferroelectrics. Proceedings of the 12th IEEE International Symposium on Applications of Ferroelectric. Honolulu, Hawaii, USA, 2000.

[32] Shankar MV, Varma KBR. Crystallization, dielectric and optical studies on strontium tetraborate glasses containing bismuth titanate. Mater Res Bull 1998, 33: 1769-1782.

[33] Molla AR, Tarafder A, Karmakar B. Synthesis and properties of glasses in the $\mathrm{K}_{2} \mathrm{O}-\mathrm{SiO}_{2}-\mathrm{Bi}_{2} \mathrm{O}_{3}-\mathrm{TiO}_{2}$ system and bismuth titanate $\left(\mathrm{Bi}_{4} \mathrm{Ti}_{3} \mathrm{O}_{12}\right)$ nano glass-ceramics thereof. $J$ Mater Sci 2011, 46: 2967-2976.

[34] Golezardi S, Marghussian VK, Beitollahi A, et al. Crystallization behavior, microstructure and dielectric properties of lead titanate glass ceramics in the presence of $\mathrm{Bi}_{2} \mathrm{O}_{3}$ as a nucleating agent. $J$ Eur Ceram Soc 2010, 30: 1453-1460.

[35] Reddy AA, Tulyaganov DU, Kapoor S, et al. Study of melilite based glasses and glass-ceramics nucleated by $\mathrm{Bi}_{2} \mathrm{O}_{3}$ for functional applications. $R S C$ Adv 2012, 2: 10955-10967.

[36] El-Meliegy E, van Noort R. Glasses and Glass Ceramics for Medical Applications. New York: Springer, 2012.

[37] Gautam CR, Kumar D, Parkash O. Controlled 
crystallization of $(\mathrm{Pb}, \mathrm{Sr}) \mathrm{TiO}_{3}$ borosilicate glass ceramics doped with $\mathrm{Nb}_{2} \mathrm{O}_{5}$. Glass Phys Chem+ 2013, 39: 162-173.

[38] Gautam CR, Kumar D, Parkash O. Crystallization behavior and microstructural analysis of lead-rich $\left(\mathrm{Pb}_{x} \mathrm{Sr}_{1-x}\right) \mathrm{TiO}_{3}$ glass ceramics containing $1 \mathrm{~mole} \%$ $\mathrm{La}_{2} \mathrm{O}_{3}$. Advances in Materials Science and Engineering 2011, 2011: 402376.

[39] Gautam CR, Kumar D, Parkash O. Crystallization behavior and microstructural analysis of strontium-rich $\left(\mathrm{Pb}_{x} \mathrm{Sr}_{1-x}\right) \mathrm{TiO}_{3}$ glass ceramics in presence of $\mathrm{La}_{2} \mathrm{O}_{3}$. Advances in Materials Science and Engineering 2011, 2011: 747346.

[40] Gautam CR, Yadav AK, Singh P. Synthesis, crystallization and microstructural study of perovskite $(\mathrm{Ba}, \mathrm{Sr}) \mathrm{TiO}_{3}$ borosilicate glass ceramic doped with $\mathrm{La}_{2} \mathrm{O}_{3}$. Mater Res Innov 2013, 17: 148-153.

[41] Patterson AL. The Scherrer formula for X-ray particle size determination. Phys Rev 1939, 56: 978-982.

[42] Sahu AK, Kumar D, Parkash O. Crystallization of lead strontium titanate perovskite phase in $\left[\left(\mathrm{Pb}_{1-x} \mathrm{Sr}_{x}\right) \mathrm{O} \cdot \mathrm{TiO}_{2}\right]-\left[2 \mathrm{SiO}_{2} \cdot \mathrm{B}_{2} \mathrm{O}_{3}\right]-\left[\mathrm{K}_{2} \mathrm{O}\right] \quad$ glass ceramics. Adv Appl Ceram 2003, 102: 139-147.

[43] Bahramia A, Nemati ZA, Alizadeh $P$, et al. Crystallization and electrical properties of $\left[\left(\mathrm{Pb}_{1-x} \mathrm{Sr}_{x}\right) \cdot \mathrm{TiO}_{3}\right]\left[\left(2 \mathrm{SiO}_{2} \cdot \mathrm{B}_{2} \mathrm{O}_{3}\right)\right]\left[\mathrm{K}_{2} \mathrm{O}\right]$ glass-ceramics. J Mater Process Tech 2008, 206: 126-131.

[44] Kumar D, Gautam CR, Parkash O. Preparation and dielectric characterization of ferroelectric $\left(\mathrm{Pb}_{x} \mathrm{Sr}_{1-x}\right) \mathrm{TiO}_{3}$ glass ceramics doped with $\mathrm{La}_{2} \mathrm{O}_{3}$. Appl Phys Lett 2006, 89: 112908.

[45] Gautam CR, Singh P, Thakur OP, et al. Synthesis, structure and impedance spectroscopic analysis of $\left[\left(\mathrm{Pb}_{x} \mathrm{Sr}_{1-x}\right) \cdot \mathrm{OTiO}_{2}\right]-\left[\left(2 \mathrm{SiO}_{2} \cdot \mathrm{B}_{2} \mathrm{O}_{3}\right)\right]-7[\mathrm{BaO}]-3\left[\mathrm{~K}_{2} \mathrm{O}\right]$ glass ceramic system doped with $\mathrm{La}_{2} \mathrm{O}_{3}$. J Mater Sci 2012, 47: 6652-6664. 